2014, volume 3, issue 1

Buszko M. (2014). Investments in stock of banks implementing high social responsibility standards listed on Warsaw Stock Exchange. Copernican Journal of Finance \& Accounting, 3(1), 45-60. http://dx.doi.org/10.12775/CJFA.2014.004

Michat Buszko*

Nicolaus Copernicus University

\title{
INVESTMENTS IN STOCK OF BANKS IMPLEMENTING \\ HIGH SOCIAL RESPONSIBILITY STANDARDS LISTED \\ ON THE WARSAW STOCK EXCHANGE
}

Keywords: CSR, RESPECT Index, Profitability.

\section{J E L Classification: G11.}

Abstract: The paper characterizes benefits and evaluates profitability of investments in stock of banks participating in RESPECT Index, i.e. a special index distinguishing companies that implement high standards of corporate social responsibility. In the paper, there is a brief characteristics of RESPECT Index, its nature, goals and ways of functioning. After that, there are presented base statistics of investors' return and risk related to the RESPECT Index. In the next part the author describes banks listed on WSE in Poland and their role in RESPECT Index. Further, there are included rates of return from investments in socially responsible banks versus WIG Banking index. The last part of the paper is related to analysis of the bank stock prices around the day of their entrance to RESPECT Index and their cumulative returns since listing within the Index on WSE.

\section{INWESTOWANIE W AKCJE BANKÓW STOSUJĄCYCH WYSOKIE STANDARDY W ZAKRESIE} SPOŁECZNEJ ODPOWIEDZIALNOŚCI BIZNESU NOTOWANYCH NA GPW W WARSZAWIE

Słowa kluczowe: CSR, RESPECT Index, Rentowność.

Date of submission: June 6, 2013; date of acceptance: November 11, 2013.

* Contact information: mibus@econ.uni.torun.pl, Department of Finance Management, Faculty of Economic Sciences and Management, Nicolaus Copernicus University, Gagarina 13a, 87-100 Toruń, Poland, phone: 566114634. 
Klasyfikacja J E L: G11.

Abstrakt: Artykuł charakteryzuje korzyści oraz ocenia rentowność inwestycji w akcje banków uczestniczących w indeksie RESPECT Index, tzn. szczególnym indeksie podkreślającym spółki stosujące wysokie standardy w zakresie społecznej odpowiedzialności biznesu. W artykule zawarto krótką charakterystyką indeksu, jego znaczenie, cele i sposoby funkcjonowania. W dalszej kolejności zaprezentowano podstawowe statystyki opisowe dotyczące rentowności oraz ryzyka inwestowania w portfel odpowiadający indeksowi RESPECT Index. W dalszej części autor charakteryzuje banki notowane na GPW w Warszawie oraz ich rolę w rozważanym indeksie. Następnie przedstawione zostały stopy zwrotu inwestorów posiadających akcje rozważanych banków na tle rentowności indeksu WIG Banki. W ostatniej części przedstawione zostały analizy dotyczące cen akcji banków w okresie ich wprowadzania do indeksu, a także skumulowane stopy zwrotu od czasu notowania banków w ramach indeksu RESPECT Index.

\section{INTRODUCTION}

Corporate social responsibility is a business philosophy that widely spreads out amongst the commercial banks in many well developed countries as well as emerging markets, like Poland. In practice, such concept become truly important after subprime crisis (2007-2009) when banks had to recover their financial condition and bring back confidence of deponents and other stakeholders. As safety of deposits and sustainable investments in 2005-2007 gave way to speculation and maximizing profits due to securitization and financial engineering, financial sector became particularly vulnerable to market risk and credit crunch. Because a role of banks as institutions of public trust had been questioned as a consequence of subprime crisis 2008-2009, a new approach to manage and control banking institutions started to be developing. In fact, the major efforts were to increase corporate social responsibility of banks to their employees, clients or investors.

As banks are special service providers in the economy, hence they have specially adjusted areas of CSR. In banking social responsibility is mostly developed in scopes of transparency and safety of operations, relations with customers, relations with employees, relations with investors and business partners, society engagement and environmental influence (Odpowiedzialny 2013; Polityka 2012). The ecological aspects of CSR in banking, which are crucial for production companies, are also vital but mostly gives way to social or those related to governance. Commonly they are reflected in promoting and financing environmental friendly projects, gathering funds for protection of natural environ- 
ment, saving energy, replacing paper documentation by electronic files as well as by enhancing ecological education of clients (Murawski 2012).

\section{THE RESEARCH METHODOLOGY AND THE COURSE OF THE RESEARCH PROCESS}

The aim of the paper is to present the investor approach to the corporate social responsibility of banks listed on Main List of the Warsaw Stock Exchange and included into RESPECT Index, i.e. first in Poland and CEE countries index of companies following developed standards of social responsibility. The author will investigate the profitability of investment in equities of banks participating in the RESPECT Index compared to the profitability of shares of other banks quoted on WSE. Also, the author will analyze if classification of the bank to the index brings additional return to the shareholder, i.e. if the CSR concept in banking influences the stock price and is positively perceived by the capital market investors (owners of banks).

The paper is divided into two major parts. The first part is related to characteristic of RESPECT Index. It contains a brief description of idea of CSR requirement in banking and presents RESPECT Index as the benchmark for effectiveness of socially responsible banks listed on WSE. Afterwards, it presents the returns of the index compared to other income-based indexes of WSE and industry subindices since the beginning of listing of RESPECT Index on 19.11.2009. In this part, there is also included a short description of 6 editions of the index which took place until the 01.06.2013. The second part is related to investigation of investments in shares of socially responsible banks. It starts from short characteristic of the banks listed on WSE. Then, it contains an analysis of prices and rate of returns on stock of banks included into RESPECT Index versus other banks listed on WSE as well as portfolio of companies included in broad index WIG. The data embraces whole life span of RESPECT index.

The author of the paper puts forward hypothesis that socially responsible banks, distinguished in RESPECT Index, brings higher returns for stock exchange investors comparing to investments other banks quoted on WSE.

\section{BANKS AND HIGH CORPORATE SOCIAL RESPONSIBILITY STANDARDS}

Due to the specifics of the banking business, its special financing, as well as their role as economic and financial intermediaries in the global economy, banks have to be ultimately transparent and conservatively balanced in their pro- 
fits generation and risks exposure. To assure their proper risk-return balance, compliance with law standards and ethics they should be governed and supervised in a special way, including participation of independent supervision institutions. As in the European model of financial market banks are prime entities providing capital for economic development, their safe, stable and responsible functioning should attract a special attention. Hence, CSR concept seems to be then particularly justified and fit for implementation in bank industry. The social responsibility of bank operations is formalized often in internal regulations, resolutions, strategic plans, as well as CSR documentation. The presentation of involvement in social responsibility is reflected primarily in banks advertisements, CSR reports, investor reports, web sites, promotional materials and events. One of the latest form of special promotion of banks listed on Warsaw Stock Exchange (WSE) that implement and develop high social responsibility standards is qualification into first in Poland and CEE countries stock exchange index of socially responsible companies - RESPECT Index ${ }^{1}$. Entering of bank into this index, confirms its high social responsibility status and indicates value creation strategy by using CSR rules in day-to-day operations. On 30th of March 2013 there were 4 banks listed within RESPECT index, however since the beginning of its quotation totally 7 banks were included.

\section{RESPECT INDEX AS A BENCHMARK OF VALUE OF SOCIAL RESPONSIBLE PUBLIC COMPANIES}

Respect Index was launched on 19.11.2009 based on the resolution of 18.11.2009 of WSE (Uchwała 2009). Such index was a first specialist index in Poland and CEE countries which has had to promote companies implementing and developing very high social responsibility standards. The index was elaborated by Kulczyk Investments altogether with Deloitte consulting company and WSE to rise interest of public companies in management based on rules of social responsibility as a method of increasing value of the company and promoting the highest standards of management in aspects: economic, ecologic and social. The main role of the index was pointing an investment attraction in stock of companies distinguishing according to quality of reporting, investor relations, information governance, corporate governance, as well as high standards of

1 Name RESPECT comes from words: Responsibility, Ecology, Sustainability, Participation, Environment, Community, Transparency. 
market, customers, management and environment relations and personnel policy (Uwarunkowania 2012).

In practice, the sense of quoting of the RESPECT Index, apart from promoting socially responsible companies, is also to distinguish WSE from other stock exchanges in Europe, pointing its modernity and progress. Also, the index has to present relative value of portfolio of companies implementing high corporate social responsibility standards. Thus, it may be used as a benchmark for valuebased management. Also, the index can be used for comparing pricing of companies implementing high CSR standards with other non-socially-responsible entities.

RESPECT Index, similarly to general index of WSE, i.e. WIG index, as well as to industry subindexes is an income-based type of index, hence it includes incomes from the dividends payouts as well as preemptive rights. The weight of each company in the index is calculated as a number of shares in the free trade subtracted by number of shares outstanding introduced into stock exchange trade, while results are rounded to thousands. In practice the share of the biggest companies in the RESPECT Index is limited to disperse the risk of following economic conditions of just few entities. In case of classification to the index less than 20 companies (what took place during $1^{\text {st }}$ and $2^{\text {nd }}$ edition), maximum share of the single company is $25 \%$, otherwise $10 \%$ (Respect 2013).

Until 2013 RESPECT Index contained only companies listed on WSE Main List, which received the highest social responsibility grading by Deloitte company - a partner of WSE in RESPECT Index project. The dual listed foreign companies and companies present in alternative trading system of NewConnect are not suitable. Deloitte conducts audit of economic, environmental, and social aspects as well as customer and investor relations of candidates (Uwarunkowania 2012). The classification to the index is in general a three stage process. The first stage is an analysis of the liquidity of trade of stock. A candidate to the Index do not participate in this part. The second stage contains investigation of standards of reporting, corporate governance and investor relations. The candidates participate in it indirectly. The third stage of the investigation relies on an opinion survey, in which companies qualified in the previous two stages are required to provide details related to their social responsibility. The information is generally collected through research questionnaire elaborated by Deloitte, containing 35 questions about policy of CSR, management system, envi-

${ }^{2}$ Until 2013 there were 6 editions of RESPECT Index announced on 19.11.2009, 25.01.2011, 25.07.2011, 31.01.2012, 31.07.2012, 24.01.2013. 
ronmental management, employment policy as well as customers and market approach (Ankieta 2012). Companies classified to the third stage are subject to Deloitte CSR audit. The refusal of participation in the survey or audit rejects the company from RESPECT Index classification.

Until 2013 there were 6 editions of RESPECT Index. The editions were held initially once and then twice per year (in January and July). In the first edition just 16 companies were qualified, of which 3 were commercial banks. In the next editions the number of companies varied between 16 do 23. Amongst companies participating in the index from its origination, there are mostly leading Polish businesses as: KGHM Polska Miedź SA, PKN Orlen SA, PGNiG SA, Telekomunikacja Polska SA, ING Bank Śląski SA, Bank Handlowy SA, Grupa Azoty SA, Elektrobudowa SA.

\section{INVESTMENT EFFECTIVENESS OF RESPECT INDEX}

When analyzing an effectiveness of RESPECT Index, one may investigate its simple rate of return. Comparing the RESPECT Index with other two income-based indexes including mostly non-socially responsible companies, i.e. WIG (broad index of WSE) and NCI (main index of alternative trading system NewConnect) one may distinguish substantial surplus of value creation of companies participating in RESPECT Index versus other entities (all data standardized on 19.11.2009). Fig 1.

Figure 1. RESPECT Index vs WIG and NCI (19.11.2009-31.03.2013)

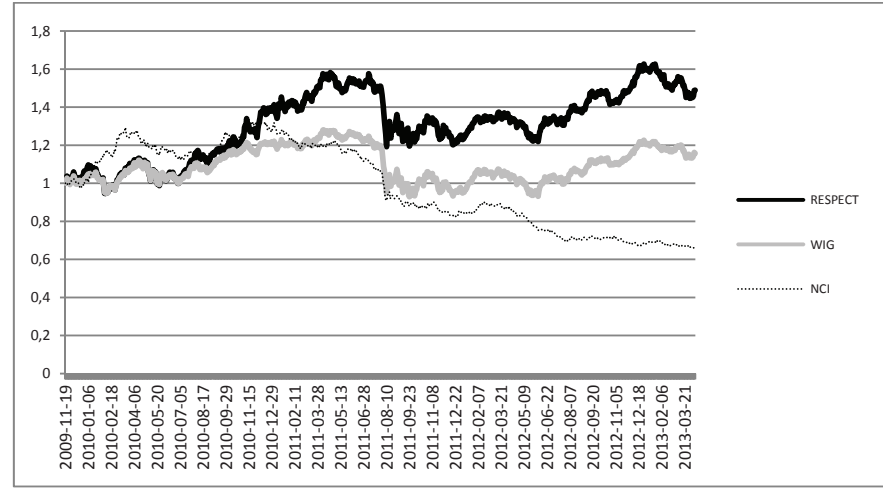

S o u r c e : own elaboration based on data of WSE. 
The annual and cumulative returns from given indexes (portfolios) are presented in Tab 1.

Table 1. Returns of RESPECT Index vs. WIG and NCI

\begin{tabular}{|c|c|c|c|}
\hline \hline Period & RESPECT & WIG & NCI \\
\hline \hline $19.11 .09-31.12 .09$ & $4,87 \%$ & $1,63 \%$ & $2,26 \%$ \\
\hline $31.12 .09-31.12 .10$ & $32,17 \%$ & $18,77 \%$ & $27,65 \%$ \\
\hline $31.12 .10-31.12 .11$ & $-11,25 \%$ & $-20,83 \%$ & $-34,39 \%$ \\
\hline $31.12 .11-31.12 .12$ & $29,23 \%$ & $26,24 \%$ & $-20,09 \%$ \\
\hline $31.12 .12-31.03 .13$ & $-7,41 \%$ & $-4,87 \%$ & $-1,68 \%$ \\
\hline $19.11 .09-31.12 .10$ & & & $30,53 \%$ \\
\hline $19.11 .09-31.12 .11$ & $38,61 \%$ & $20,70 \%$ & $-14,36 \%$ \\
\hline $19.11 .09-31.12 .12$ & $23,02 \%$ & $-4,44 \%$ & $-31,56 \%$ \\
\hline $19.11 .09-31.03 .13$ & $58,98 \%$ & $20,63 \%$ & $-32,72 \%$ \\
\hline \hline
\end{tabular}

S o u r c e : own elaboration based on data of WSE.

Tab 1. confirms that RESPECT Index on average brings higher returns to investors comparing to other portfolios of companies that do not distinguish by high standards of social responsibility.

In general RESPECT index represents mainly 5-6 major industries, i.e. Oil\&gas, Raw materials, Banking, Telecommunication, Energy and Insurance, while each industry is represented by 1 to 3 companies $^{3}$. The share of each industry varies in each edition of the index and is related to the total number of companies participating in the index. The history of the RESPECT Index confirms a permanent dominance of the Oil\&gas and Raw materials industries. In the first edition in 2009, they concentrated approx. $60,6 \%$ of share of the Index, and in the first edition in 2013 (VI edition totally), their share was 46,4\%. Banking share started from approx. 14\% in 2009 and leveled at 11,3\% in 2013. Tab 2. presents major statistics of RESPECT index versus other indexes and major industries subindexes represented by companies participating in RESPECT.

3 Banking sector was represented in II, IV and V edition by 5 entities and in III edition by 6 entities. 
Table 2. Major statistics of RESPECT Index vs. WIG, NCI and industry subindexes

\begin{tabular}{|l|c|c|c|c|c|c|c|c|c|}
\hline \hline \multicolumn{1}{|c|}{ Index } & RESPECT & WIG & NCI & $\begin{array}{c}\text { WIG } \\
\text { Energy }\end{array}$ & $\begin{array}{c}\text { WIG } \\
\text { Oil\&gas }\end{array}$ & $\begin{array}{c}\text { WIG Raw } \\
\text { materials }\end{array}$ & $\begin{array}{c}\text { WIG } \\
\text { Banking }\end{array}$ & $\begin{array}{c}\text { WIG } \\
\text { Telecom }\end{array}$ & $\begin{array}{c}\text { WIG } \\
\text { Chemicals }\end{array}$ \\
\hline \hline St. dev. & $1,23 \%$ & $1,10 \%$ & $0,79 \%$ & $1,22 \%$ & $1,56 \%$ & $2,03 \%$ & $1,50 \%$ & $1,64 \%$ & $1,63 \%$ \\
\hline Max.chg & $4,75 \%$ & $4,69 \%$ & $2,71 \%$ & $6,39 \%$ & $5,91 \%$ & $5,90 \%$ & $7,34 \%$ & $8,19 \%$ & $8,08 \%$ \\
\hline Min. chg & $-6,02 \%$ & $-6,05 \%$ & $-4,49 \%$ & $-6,50 \%$ & $-7,81 \%$ & $-11,52 \%$ & $-7,48 \%$ & $-24,57 \%$ & $-9,86 \%$ \\
\hline $\begin{array}{l}\text { Average } \\
\text { Chng. >=0 }\end{array}$ & $0,90 \%$ & $0,75 \%$ & $0,57 \%$ & $0,84 \%$ & $1,00 \%$ & $0,90 \%$ & $1,09 \%$ & $1,18 \%$ & $0,95 \%$ \\
\hline $\begin{array}{l}\text { Average } \\
\text { Chng. }<0\end{array}$ & $-0,91 \%$ & $-0,81 \%$ & $-0,60 \%$ & $-1,03 \%$ & $-1,07 \%$ & $-0,92 \%$ & $-1,04 \%$ & $-1,15 \%$ & $-1,05 \%$ \\
\hline Kurtosis & 2,37119 & 3,8260 & 2,06247 & 4,7659 & 3,4591 & 2,5861 & 1,5943 & 2,0823 & 62,7335 \\
\hline Skewness & $-30,67 \%$ & $-53,14 \%$ & $-22,92 \%$ & $-98,84 \%$ & $-42,59 \%$ & $-28,71 \%$ & $9,54 \%$ & $-22,60 \%$ & $-447,5 \%$ \\
\hline R Coeff. & $100,0 \%$ & $92,95 \%$ & $38,02 \%$ & $65,44 \%$ & $86,57 \%$ & $78,57 \%$ & $79,27 \%$ & $48,11 \%$ & $55,19 \%$ \\
\hline \hline
\end{tabular}

S o u r c e : own elaboration of WSE data.

RESPECT index as a portfolio of companies was more efficient since its origins than almost all of the industry subindices of WSE. The only exceptions were WIG Chemicals and WIG Oil\&gas which have generated surplus over RESPECT. The long-term cumulative rates of return for RESPECT and other subindices in period 19.11.2009-31.03.2013 are as follows: WIG Chemicals 232,14\%, WIG Oil\&gas 62,79\%, RESPECT 47,20\%, WIG Food 11,95\%, WIG Banking 9,89\%, WIG Raw materials 0,17\%, WIG IT -7,60\%, WIG Energy -14,28\%, WIG Telecom $-38,01 \%$, WIG Developers $-55,33 \%$, WIG Construction $-67,22 \%$. The general profitability of the RESPECT Index portfolio in the previous years was dependent primarily on economic conditions of a few crucial companies of Oil\&gas, Chemicals, Raw Materials and Banking Industries.

\section{PROFITABILITY OF INVESTMENTS IN STOCK OF SOCIALLY RESPONSIBLE BANKS}

On 31.03.2013 there were totally 17 commercial banks out of 439 companies listed on WSE. Among them there were two foreign banks, UNICREDIT S.P.A. from Italy and NOVA KREDITNA BANKA MARIBOR D.D. from Slovenia listed parallel to foreign markets. Capitalization, assets and equity value of listed banks vary, however permanently $4-5$ banks out of 17 has been amongst 10 biggest companies considering market value. Two leading banks listed on WSE are PKOBP SA and PEKAO SA and their market value at the end of March 2013 
was 43,19 bln PLN and 41,2 bln PLN. At the same time the entities with a value exceeding 5 bln PLN were as follows: BZ WBK 23,6 bln PLN, BRE Bank SA 14,4 bln PLN, Bank Handlowy SA 11,9 bln PLN, ING Bank Śląski SA 11,8 bln PLN, Bank Millennium SA 5,8 bln PLN.

Despite lack of proper liquidity of trade just 13 banks (including 2 foreign entities) out of 17 are included into broad index of WSE (WIG) as well as industry subindex WIG Banking. Among them there is a specialized bank oriented in ecological financing and supporting natural environment projects - BOŚ Bank SA, however this entity is not included in the RESPECT Index.

Within the group of commercial banks listed on WSE there are two banks participating permanently in the RESPECT index from the $1^{\text {st }}$ edition, i.e. Bank Handlowy SA and ING Bank Śląski SA. Both entities belongs to the international financial groups created by Citigroup and ING which implement high social responsibility standards in international scope (Dziawgo 2010). Apart from two mentioned banks, one entity is present from $2^{\text {nd }}$, i.e. Bank Millennium SA. Bank BPH SA, entered the index in the $1^{\text {st }}$ edition, however left it in the $2^{\text {nd }}$ and returned in $4^{\text {th }}$. There were also three other banks included in RESPECT: i.e. BRE Bank SA and BZ WBK SA in the $2^{\text {nd }}$ edition, as well as Kredyt Bank SA included in the $3^{\text {rd }}$ edition. All of three entities are not present in the index as on 31.03.2013 ( $6^{\text {th }}$ edition). Nonetheless BZ WBK SA and Kredyt Bank SA were excluded not due to deterioration of CSR standards but due to takeovers. Tab 3. presents the rates of return from investments in socially responsible banks (including dividends) for periods starting 1 year before entering the index and finishing 1 year after.

Table 3. Rates of return on stock of banks included into RESPECT Index

\begin{tabular}{|c|c|c|c|c|c|c|c|c|c|c|}
\hline \hline $\begin{array}{c}\text { Rate } \\
\text { of return }\end{array}$ & $\begin{array}{c}\text { Handlo- } \\
\text { wy }\end{array}$ & $\begin{array}{c}\text { ING } \\
\text { BSK }\end{array}$ & BPH & $\begin{array}{c}\text { Millen- } \\
\text { nium }\end{array}$ & $\begin{array}{c}\text { BZ } \\
\text { WBK }\end{array}$ & BRE & $\begin{array}{c}\text { Kredyt } \\
\text { Bank }\end{array}$ & BPH (2) & Mean & Med. \\
\hline \hline$-1 \mathrm{~d} /+1 \mathrm{~d}$ & $-4,1 \%$ & $-1,4 \%$ & $-0,6 \%$ & $0,8 \%$ & $0,7 \%$ & $-0,1 \%$ & $-0,40 \%$ & $0,4 \%$ & $-0,6 \%$ & $-0,4 \%$ \\
\hline$-1 \mathrm{w} /+1 \mathrm{w}$ & $-0,4 \%$ & $-2,8 \%$ & $4,3 \%$ & $8,6 \%$ & $1,9 \%$ & $2,1 \%$ & $-1,79 \%$ & $14,9 \%$ & $3,4 \%$ & $2,1 \%$ \\
\hline$-1 \mathrm{~m} /+1 \mathrm{~m}$ & $17,5 \%$ & $22,8 \%$ & $16,7 \%$ & $11,1 \%$ & $5,9 \%$ & $2,1 \%$ & $-20,29 \%$ & $34,1 \%$ & $11,2 \%$ & $11,2 \%$ \\
\hline$-3 \mathrm{~m} /+3 \mathrm{~m}$ & $18,2 \%$ & $27,9 \%$ & $15,7 \%$ & $14,3 \%$ & $7,9 \%$ & $24,9 \%$ & $-17,43 \%$ & $-6,7 \%$ & $10,6 \%$ & $14,3 \%$ \\
\hline$-6 \mathrm{~m} /+6 \mathrm{~m}$ & $38,5 \%$ & $114,2 \%$ & $72,0 \%$ & $14,3 \%$ & $22,4 \%$ & $21,1 \%$ & $-35,33 \%$ & $-37,1 \%$ & $25,7 \%$ & $21,1 \%$ \\
\hline$-1 \mathrm{y} /+1 \mathrm{y}$ & $112,7 \%$ & $117,6 \%$ & $97,1 \%$ & $-2,6 \%$ & $26,4 \%$ & $5,6 \%$ & $-17,09 \%$ & $-26,9 \%$ & $37,5 \%$ & $22,1 \%$ \\
\hline \hline
\end{tabular}

S o u r c e : own elaboration of WSE data. 
All the investments in the banks' shares gave positive average rates of return, except purchase of shares 1 day before entering the index and selling on the entering date.

To assess the profitability of investments, the author used also banks stock rates of return adjusted by rate of return of industry subindex WIG Banking. Such subindex represents primarily banks non distinguished by CSR policy, so it can be treated as a benchmark for CSR investor return. Approx. 87\% of WIG Banking index is actually represented by the banks not included in RESPECT Index. That way investor may get differencing between CSR and non-CSR investment. The results are presented in Tab 4.

Table 4. Adjusted rates of return on stock of banks joining RESPECT Index

\begin{tabular}{|c|c|c|c|c|c|c|c|c|c|c|}
\hline \hline $\begin{array}{c}\text { Rate of } \\
\text { return }\end{array}$ & $\begin{array}{c}\text { Handlo- } \\
\text { wy }\end{array}$ & $\begin{array}{c}\text { ING } \\
\text { BSK }\end{array}$ & BPH & $\begin{array}{c}\text { Millen- } \\
\text { nium }\end{array}$ & $\begin{array}{c}\text { BZ } \\
\text { WBK }\end{array}$ & BRE & $\begin{array}{c}\text { Kredyt } \\
\text { Bank }\end{array}$ & BPH (2) & Mean & Med. \\
\hline \hline$-1 \mathrm{~d} /+1 \mathrm{~d}$ & $-1,3 \%$ & $1,4 \%$ & $2,2 \%$ & $1,4 \%$ & $1,3 \%$ & $0,5 \%$ & $0,3 \%$ & $-0,3 \%$ & $0,7 \%$ & $0,7 \%$ \\
\hline$-1 \mathrm{w} /+1 \mathrm{w}$ & $3,1 \%$ & $0,7 \%$ & $7,8 \%$ & $9,1 \%$ & $2,3 \%$ & $2,5 \%$ & $-2,2 \%$ & $8,1 \%$ & $3,9 \%$ & $3,1 \%$ \\
\hline$-1 \mathrm{~m} /+1 \mathrm{~m}$ & $13,4 \%$ & $18,7 \%$ & $12,6 \%$ & $15,6 \%$ & $10,3 \%$ & $6,5 \%$ & $-2,9 \%$ & $24,9 \%$ & $12,4 \%$ & $12,6 \%$ \\
\hline$-3 \mathrm{~m} /+3 \mathrm{~m}$ & $-3,0 \%$ & $6,7 \%$ & $-5,5 \%$ & $10,5 \%$ & $4,1 \%$ & $21,2 \%$ & $2,0 \%$ & $-3,5 \%$ & $4,1 \%$ & $4,1 \%$ \\
\hline$-6 \mathrm{~m} /+6 \mathrm{~m}$ & $-18,6 \%$ & $57,2 \%$ & $15,0 \%$ & $5,5 \%$ & $13,7 \%$ & $12,4 \%$ & $-19,2 \%$ & $-22,8 \%$ & $4,9 \%$ & $5,5 \%$ \\
\hline$-1 \mathrm{y} /+1 \mathrm{y}$ & $34,6 \%$ & $39,6 \%$ & $19,1 \%$ & $3,9 \%$ & $32,9 \%$ & $12,0 \%$ & $-6,0 \%$ & $-20,1 \%$ & $12,9 \%$ & $12,9 \%$ \\
\hline \hline
\end{tabular}

S o u r c e : own elaboration.

The results presented in Tab 4. shows that the investments in socially responsible banks' stock is on average more profitable than investments in shares of banks not included in RESPECT index, while the highest surplus between rates of return are found in investments starting 1 year or 1 month before entering the index and terminating 1 year or 1 month after 4 .

\section{INVESTMENT PROFITS DUE TO ENTERING RESPECT INDEX BY BANKS}

An analysis of the profitability of investments in shares of banks socially responsible can be enlarged by investigation of prices of stock in short period aro-

${ }^{4}$ Banks included in the RESPECT Index got also higher returns for all the periods comparing to the broad market index WIG, except $-1 \mathrm{~d} /+1 \mathrm{~d}$ period of investment. 
und the date of entering the RESPECT Index. The investigation had to find out if the event of entering the index had any influence on the pricing of the bank, and if yes, what was the scope of such influence. To check the potential change of market price the author had normalized market price of a bank stock, assuming the entering date as $100 \%$ and analyzed its change in the period $-1 \mathrm{~m} /+1 \mathrm{~m}$ around RESPECT Index entering date. Also, the investigation was complemented by analysis of normalized market price of a share adjusted by a normalized value of the WIG Banking index, which was treated as a benchmark for abnormal profitability measure. Choosing of $-1 \mathrm{~m} /+1 \mathrm{~m}$ had to give some outlook on the investor reaction on the distinction of a bank through listing it in the portfolio of RESPECT Index.

Fig. 2. and 3. present normalized pricing of banks entering the RESPECT Index during its $1^{\text {st }}$ edition announced on 19.11.2009 (Bank Handlowy SA, ING Bank Śląski SA, BPH SA). Fig. 4. and 5. present pricing of banks in the $2^{\text {nd }}$ edition of the Index announced on 25.01.2011 (BRE Bank SA, Bank Millennium SA and Bank Zachodni WBK SA). Fig. 6. and 7. shows pricing of Kredyt Bank SA during the $3^{\text {rd }}$ edition of the index announced on 25.07.2011, while Fig. 8. and 9. presents second entrance of BPH bank to the RESPECT Index in its $4^{\text {th }}$ edition announced on 31.01.2012 after exclusion in the second edition. No banks joined the index in the V and VI editions announced on 31.07.2012 and 24.01.2013.

Figure 2. Normalized prices of banks entering RESPECT Index in the $1^{\text {st }} \mathrm{ed}$.

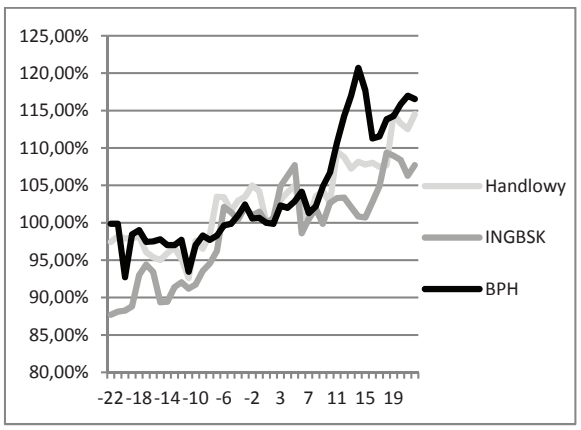

S o u r c e : own elaboration of WSE data.
Figure 3. Normalized prices of banks entering RESPECT Index in the $1^{\text {st }}$ ed. adjusted by WIG Banking

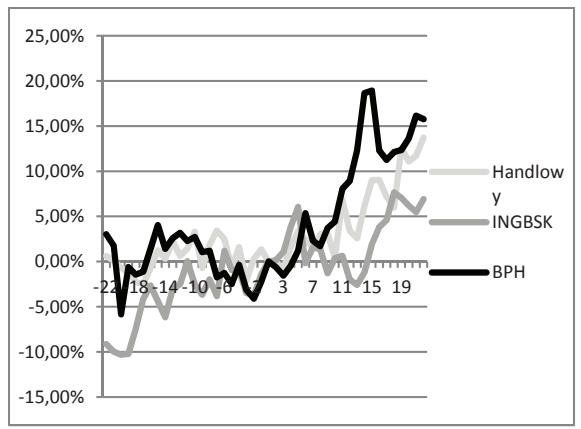

S o u r c e : own elaboration of WSE data. 
Figure 4. Normalized prices of banks entering RESPECT Index in the $2^{\text {nd }} \mathrm{ed}$.

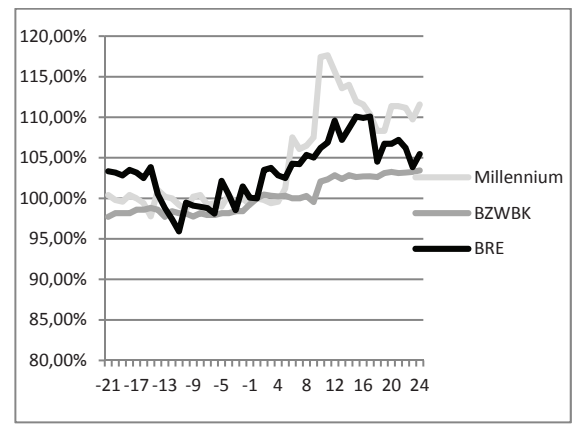

S o u r c e : own elaboration of WSE data.

Figure 6. Normalized prices of the bank entering RESPECT Index in the $3^{\text {rd }}$ ed.

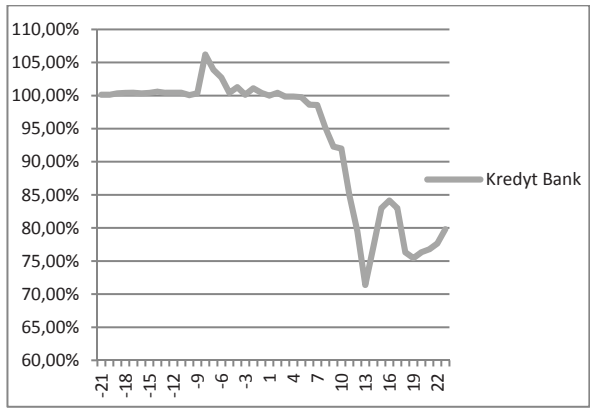

S o u r c e : own elaboration of WSE data.
Figure 5. Normalized prices of banks entering RESPECT Index in the 2 nd ed. adjusted by WIG Banking

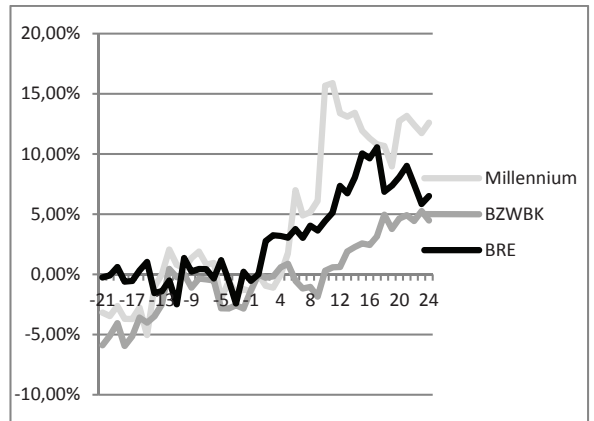

S o u r c e : own elaboration of WSE data.

Figure 7. Normalized prices of bank entering RESPECT Index in the $3^{\text {rd }}$ ed. adjusted by WIG Banking

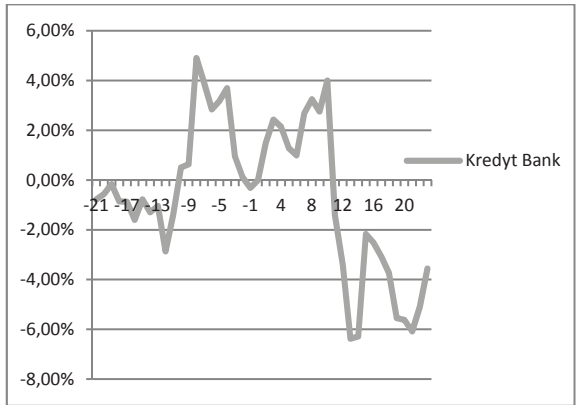

S o u r c e : own elaboration of WSE data.

All of the presented investments in shares of banks that entered RESPECT Index increased in absolute as well as relative way wealth of the shareholders, except of Kredyt Bank SA. The included figures may confirm that a fact of distinguishing the high social responsibility standards implemented by bank is accepted and positively perceived by stock exchange investors in a short period of time ${ }^{5}$. In case of Kredyt Bank SA, the lack of immediate benefits related to

${ }^{5}$ An analysis of investment benefits due to participation in the RESPECT index in the long-term would be substantially distorted by other factors influencing the stock price but not related to CSR implementation. 
Figure 8. Normalized prices of the bank entering RESPECT Index in the $4^{\text {th }}$ ed.

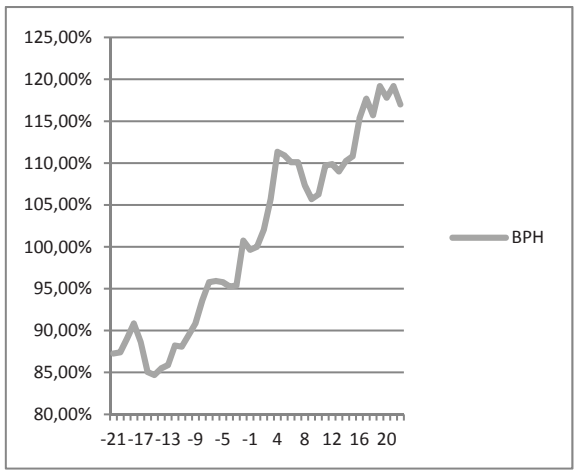

S o u r c e : own elaboration of WSE data.
Figure 9. Normalized prices of bank entering RESPECT Index in the $4^{\text {th }}$ ed. adjusted by WIG Banking

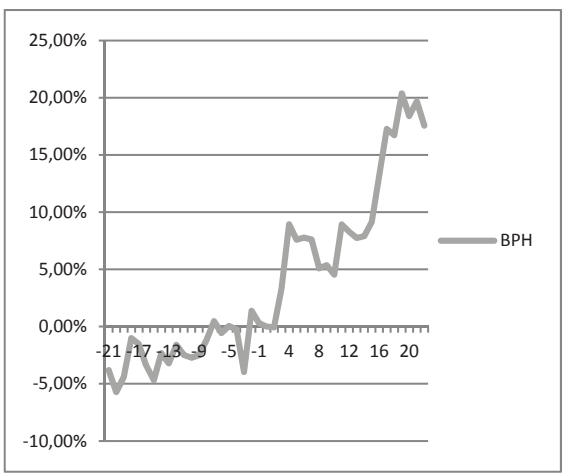

S o u r c e : own elaboration of WSE data.

participation in the index might be justified by general financial market disturbances due to debt crisis in eurozone and foreseen disposal of the bank by its owner, i.e. Belgian financial group KBC.

Despite stock exchange investors positively perceived entering banks into RESPECT index, the long-term cumulative rate of return on their stock (including dividends) is lower comparing to the rate of whole portfolio of RESPECT Index. Tab 5.

Table 5. Cumulative rates of return of banks participating in RESPECT vs. other indices

\begin{tabular}{|l|c|c|c|c|c|c|c|c|c|c|}
\hline \hline Period & $\begin{array}{c}\text { Handlo- } \\
\text { wy }\end{array}$ & $\begin{array}{c}\text { ING } \\
\text { BSK }\end{array}$ & BPH & $\begin{array}{c}\text { Millen- } \\
\text { nium }\end{array}$ & BZ WBK & $\begin{array}{c}\text { Kredyt } \\
\text { Bank }\end{array}$ & BRE & Mean & $\begin{array}{c}\text { WIG } \\
\text { Banking }\end{array}$ & RESP \\
\hline \hline $\begin{array}{l}\mathbf{1 9 . 1 1 . 0 9 -} \\
\mathbf{3 1 . 1 2 . 0 9}\end{array}$ & $5,74 \%$ & $9,09 \%$ & $19,54 \%$ & $17,36 \%$ & $7,34 \%$ & $3,04 \%$ & $8,02 \%$ & $10,02 \%$ & $1,27 \%$ & $4,87 \%$ \\
\hline $\begin{array}{l}\mathbf{3 1 . 1 2 . 0 9 -} \\
\mathbf{3 1 . 1 2 . 1 0}\end{array}$ & $38,96 \%$ & $14,62 \%$ & $-17,18 \%$ & $4,17 \%$ & $15,21 \%$ & $24,14 \%$ & $16,92 \%$ & $13,83 \%$ & $17,93 \%$ & $32,17 \%$ \\
\hline $\begin{array}{l}\mathbf{3 1 . 1 2 . 1 0} \\
\mathbf{3 1 . 1 2 . 1 1}\end{array}$ & $-24,31 \%$ & $-10,40 \%$ & $-54,32 \%$ & $-24,00 \%$ & $6,90 \%$ & $-30,86 \%$ & $-19,08 \%$ & $-22,30 \%$ & $-21,68 \%$ & $-11,25 \%$ \\
\hline $\begin{array}{l}\mathbf{3 1 . 1 2 . 1 1 -} \\
\mathbf{3 1 . 1 2 . 1 2}\end{array}$ & $37,27 \%$ & $13,61 \%$ & $48,55 \%$ & $16,32 \%$ & $6,79 \%$ & $62,24 \%$ & $32,52 \%$ & $31,04 \%$ & $22,64 \%$ & $29,23 \%$ \\
\hline $\begin{array}{l}\mathbf{3 1 . 1 2 . 1 2} \\
\mathbf{3 1 . 0 3 . 1 3}\end{array}$ & $-9,95 \%$ & $-0,22 \%$ & $2,99 \%$ & $8,60 \%$ & $0,84 \%$ & - & $4,91 \%$ & $1,19 \%$ & $-4,20 \%$ & $-7,41 \%$ \\
\hline
\end{tabular}




\begin{tabular}{|c|c|c|c|c|c|c|c|c|c|c|}
\hline \hline Period & $\begin{array}{c}\text { Handlo- } \\
\text { wy }\end{array}$ & $\begin{array}{c}\text { ING } \\
\text { BSK }\end{array}$ & BPH & $\begin{array}{c}\text { Millen- } \\
\text { nium }\end{array}$ & BZ WBK & $\begin{array}{c}\text { Kredyt } \\
\text { Bank }\end{array}$ & BRE & Mean & $\begin{array}{c}\text { WIG } \\
\text { Banking }\end{array}$ & RESP \\
\hline \hline $\begin{array}{l}\mathbf{1 9 . 1 1 . 0 9 -} \\
\mathbf{3 1 . 1 2 . 1 0}\end{array}$ & $46,93 \%$ & $25,03 \%$ & $-1,00 \%$ & $22,25 \%$ & $23,67 \%$ & $27,91 \%$ & $26,30 \%$ & $24,44 \%$ & $19,42 \%$ & $38,61 \%$ \\
\hline $\begin{array}{l}\mathbf{1 9 . 1 1 . 0 9 -} \\
\mathbf{3 1 . 1 2 . 1 1}\end{array}$ & $11,21 \%$ & $12,03 \%$ & $-54,78 \%$ & $-7,09 \%$ & $32,20 \%$ & $-11,57 \%$ & $2,20 \%$ & $-2,26 \%$ & $-6,46 \%$ & $23,02 \%$ \\
\hline $\begin{array}{l}\mathbf{1 9 . 1 1 . 0 9 -} \\
\mathbf{3 1 . 1 2 . 1 2}\end{array}$ & $52,66 \%$ & $27,27 \%$ & $-32,82 \%$ & $8,07 \%$ & $41,19 \%$ & $43,48 \%$ & $35,44 \%$ & $25,04 \%$ & $14,71 \%$ & $58,98 \%$ \\
\hline $\begin{array}{l}\mathbf{1 9 . 1 1 . 0 9 -} \\
\mathbf{3 1 . 0 3 . 1 3}\end{array}$ & $37,46 \%$ & $26,99 \%$ & $-30,81 \%$ & $17,36 \%$ & $42,37 \%$ & - & $42,09 \%$ & $22,58 \%$ & $9,89 \%$ & $47,20 \%$ \\
\hline \hline
\end{tabular}

S o u r c e : own elaboration of WSE data.

Tab. 5 confirms that portfolio of banks participating in RESPECT index is generally less profitable than the entire portfolio of RESPECT, however it is more profitable than portfolio of WIG Banking subindex.

An analysis of profitability of investments in stock of banks included in RESPECT Index can be supplemented by statistics based on monthly returns and risk on shares and indices calculated since introduction of RESPECT index on WSE Tab. 6.

Table 6. Monthly returns statistics of banks participating in RESPECT Index vs returns of WIG Banking and RESPECT

\begin{tabular}{|l|c|c|c|c|c|c|c|c|c|}
\hline \hline \multicolumn{1}{|c|}{ Category } & $\begin{array}{c}\text { Handlo- } \\
\text { wy }\end{array}$ & $\begin{array}{c}\text { ING } \\
\text { BSK }\end{array}$ & BPH & $\begin{array}{c}\text { Millen- } \\
\text { nium }\end{array}$ & $\begin{array}{c}\text { BZ } \\
\text { WBK }\end{array}$ & $\begin{array}{c}\text { Kredyt } \\
\text { Bank }\end{array}$ & BRE & $\begin{array}{c}\text { WIG } \\
\text { Banking }\end{array}$ & RESP \\
\hline \hline Mean & $1,00 \%$ & $0,71 \%$ & $-0,29 \%$ & $0,73 \%$ & $0,99 \%$ & $1,44 \%$ & $1,20 \%$ & $0,38 \%$ & $1,05 \%$ \\
\hline St. dev. & $7,06 \%$ & $5,57 \%$ & $10,35 \%$ & $8,53 \%$ & $5,84 \%$ & $10,19 \%$ & $8,83 \%$ & $5,70 \%$ & $5,42 \%$ \\
\hline Mean/St.dev & $14,15 \%$ & $12,78 \%$ & $-2,81 \%$ & $8,60 \%$ & $16,91 \%$ & $14,18 \%$ & $13,63 \%$ & $6,69 \%$ & $19,37 \%$ \\
\hline R coefficient & $70,04 \%$ & $71,27 \%$ & $49,86 \%$ & $54,30 \%$ & $34,77 \%$ & $50,48 \%$ & $63,65 \%$ & $80,36 \%$ & $100,00 \%$ \\
\hline $\begin{array}{l}\text { Regr. } \\
\text { Coefficient }\end{array}$ & 1,0071 & 0,8290 & 1,1735 & 1,0647 & 0,4758 & - & 1,3416 & 1,0620 & 1,0496 \\
\hline \hline
\end{tabular}

S o u r c e : own elaboration of WSE data.

Presented data confirms that most of the banks ever participating in RESPECT has higher average returns comparing to WIG Banking Index as well as higher standard deviation reflecting their increased investment risk level. The relationship between those two categories gives advantage to the socially responsible banks over other entities represented by WiG Banking. Nonetheless, 
socially responsible banks stock is less profitable and more risky than the portfolio of RESPECT Index.

\section{ConCLUSIONS}

Banks are entities that actively implement and develop social responsibility standards. Their engagement in this field is visible clearly after financial crisis of 2007-2009. The most common socially responsible actions of banks are related to employees training, financing of ecological projects, saving energy and protecting of natural environment, developing transparent relations with customers and deponents as well as providing high quality, detailed reporting to investors. In Poland majority of banks provides social responsible operations and in some cases also developed complex CSR policies. As the WSE elaborated and started to list RESPECT index that promotes and specially distinguishes companies that implement very high CSR standards, totally 7 banks were qualified. The investigation included in this paper showed that investors may get benefits due to investments in stock of banks socially responsible, both in absolute as well as relative way. The hypothesis put forward by the author can be verified positively. The lowest return is generally achieved in the shortest - one day period of investment in stock of banks joining the index. The highest return is obtained from the long term investments, what confirms the strategic character of CSR policy. Despite visible changes of pricings of banks stock due to the quotation within RESPECT Index one has to consider that the Index itself is still quite a new concept in Poland. That means its formula is still changing as well as rules of classification of companies. Thus, the banks participating in the index may not be representing similar CSR quality. Also, one has to note still very small number of companies promoted by the index. In case of banks there were maximum 5 entities listed simultaneously within RESPECT but their number was changing in following editions due exclusions as well as mergers and acquisitions. A small number of banks, relatively short period of functioning of RESPECT Index and a lack of sufficient long time series hinder application of advanced statistical methods of analysis to check thoroughly the value creation for capital markets investors. Nonetheless promoting of social responsibility amongst the banks should be developed in long-term period as the preliminary research confirm its benefits. 


\section{REFERENCES}

Ankieta RESPECT - VI edycja 2012 r. (2013) Giełda Papierów Wartościowych w Warszawie, http://www.odpowiedzialni.gpw.pl/pub/ankieta_VI_edycja.pdf (accessed: 25.04.2013).

Dziawgo L. Zielony rynek finansowy. Ekologiczna ewolucja rynku finansowego, PWE, Warszawa 2010, p. 111-113.

Murawski T. (2012), Społeczna odpowiedzialność biznesu jako kierunek rozwoju rynku finansowego - ujęcie współczesne, Annales Universitatis Mariae Curie-Skłodowska, UMCS, Lublin, 628.

Odpowiedzialny biznes w Banku Millennium, http://www.bankmillennium.pl/static-content/PL/CSR_w_Banku_Millennium_prezentacja_537047.pdf (accessed: 01.06. 2013).

Polityka społecznej odpowiedzialności i zrównoważonego rozwoju Banku Zachodniego WBK (2012), Załącznik do Zarządzenia Prezesa Zarządu nr 32/2012 z dnia 07.12.2012 r., Bank Zachodni WBK, http://www.bzwbk.pl/_items/bzwbk.pl/pdf/polityka-csr-bz-wbk.pdf (accessed: 30.05.2013).

Respect Index. Opis projektu, Giełda Papierów Wartościowych w Warszawie (2013), http://www.odpowiedzialni.gpw.pl/opis_projektu (accessed: 25.04.2013).

Uchwała Nr 651/2009, Zarządu Giełdy Papierów Wartościowych w Warszawie S.A. z dnia 18 listopada 2009 r., GPW w Warszawie, http://www.gpwinfostrefa.pl/GPWIS2/pl/ archive/info/!5155004,gpw:-nowy-indeks--respect-index- (accessed: 20.04.2013).

Uwarunkowania związane z przygotowaniem spółki do weryfikacji. RESPECT Index (2012), Deloitte, http://www.odpowiedzialni.gpw.pl/pub/KRI_-_prezentacja_Deloitte.pdf (accessed: 28.05.2013). 